OPEN ACCESS

Citation: Rochele Allgayer, Gizele de Souza (2021) The wonders of the Planetarium: intents and pitfalls for the implementation of a scientific facility in the midst of educational debates in Brazil in 1930s. Rivista di Storia dell'Educazione 8(1): 25-36. doi: $10.36253 /$ rse-10023

Received: November 16, 2021

Accepted: May 19, 2021

Published: July 5, 2021

Copyright: (c) 2021 Rochele Allgayer, Gizele de Souza. This is an open access, peer-reviewed article published by Firenze University Press (http:// www.fupress.com/rse) and distributed under the terms of the Creative Commons Attribution License, which permits unrestricted use, distribution, and reproduction in any medium, provided the original author and source are credited.

Data Availability Statement: All relevant data are within the paper and its Supporting Information files.

Competing Interests: The Author(s) declare(s) no conflict of interest.

Editor: Rossella Raimondo, Università di Bologna.

\section{The wonders of the Planetarium: intents and pitfalls for the implementation of a scientific facility in the midst of educational debates in Brazil in the 1930s}

\author{
Le meraviglie del Planetario: intenti e insidie per la realizzazione \\ di una struttura scientifica nel bel mezzo dei dibattiti educativi \\ nel Brasile degli anni '30
}

\author{
Rochele Allgayer, Gizele de Souza \\ Federal University of Paraná/Brazil \\ E-mail: allgayer.rochele@gmail.com; gizelesouza@ufpr.br
}

\begin{abstract}
This study aims to highlight some articulations the intent of which was to set up Brazil's first Planetarium in Rio de Janeiro during the organization of the $4^{\text {th }}$ National Education Conference and pedagogy exposition in 1931. The Conferences, promoted by the Brazilian Education Association (ABE), were founded on strategies for disseminating educational practices and producing material for Brazilian schools. This mechanism was a tool not only to provide visibility but also to promote the debate on the material conditions needed for public education. ABE developed actions aimed at directing and political organizing of the school education system in Brazil. Its work was marked by the holding of debates, surveys, research, exhibitions, libraries, publications, conferences and courses that contributed to the entire education process. However, its national prominence occurred through its organization of the National Education Conferences with effect from 1927. The Conferences were not only a way of giving visibility to modern and up to data schooling but also for fuelling the debate on material conditions needed for public education. The ABE Conferences served as a link between the federal government, the state government and civil society, as well as being an important strategy for disseminating ideas. They gave rise to a variety of themes, actions and proposals capable of disseminating educational causes on a national level, addressed at the Conferences and publicized by the press of that time. Among them, this text highlights the debate and the attempt to acquire Brazil's first Planetarium which could have been part of the activities of the $4^{\text {th }}$ National Education Conference scheduled for 1931. In addition, the debate could put the subject of planetariums into circulation - as a modern mechanism, a powerful instrument used not only by the population but also by science and education in other countries. This article addresses aspects of material school culture by exploring sources derived from the archives of the Brazilian Education Association and from the Brazilian periodical press, proposing relationships and analyses of the use of narrative of the rhetoric of modernity in education. The theoretical references to assist with analysis are linked to the perspective of studies on material school culture and cultural history.
\end{abstract}

Keywords: material school culture, national education conferences, planetarium, pedagogy exposition, cultural history. 
Riassunto. L'obiettivo di questo studio è quello di evidenziare alcune articolazioni il cui intento era l'installazione del primo Planetario brasiliano a Rio de Janeiro durante l'organizzazione della 4a Conferenza Nazionale sull'Educazione e la Mostra sulla Pedagogia tenutesi nel 1931. Le Conferenze, promosse dall'Associazione Brasiliana per l'Educazione (ABE), si basavano su strategie per la diffusione di pratiche educative e la produzione di materiale per le scuole brasiliane. Questo meccanismo fu uno strumento non solo per dare visibilità, ma anche per promuovere il dibattito sulle condizioni materiali necessarie per la pubblica istruzione. L'ABE sviluppò azioni indirizzate alla direzione e allorganizzazione politica del sistema educativo scolastico in Brasile. Il lavoro di questa Associazione fu caratterizzato dallo svolgimento di dibattiti, inchieste, ricerche, mostre, biblioteche, pubblicazioni, conferenze e corsi che contribuirono all'intero processo educativo. Tuttavia, la sua rilevanza nazionale avvenne mediante l'organizzazione delle Conferenze Nazionali sull'Educazione a partire dal 1927. Le Conferenze non furono solo un modo di dare visibilità alla scuola moderna e al rispettivo aggiornamento, ma anche per sostenere il dibattito sulle condizioni materiali necessarie per la pubblica istruzione. Le Conferenze dell'ABE servirono da collegamento tra il Governo Federale, il Governo degli Stati e la società civile, inoltre ad essere un'importante strategia per la diffusione delle idee. Da esse scaturì una molteplicità di temi, azioni e proposte capaci di diffondere cause educative a livello nazionale, temi discussi nelle Conferenze e pubblicizzati dalla stampa dell'epoca. Tra questi, questo testo evidenzia il dibattito ed il tentativo di acquisire il primo Planetario del Brasile che avrebbe potuto far parte delle attività della 4a Conferenza Nazionale sull'Educazione prevista per il 1931. Inoltre, il dibattito avrebbe potuto mettere in circolazione il tema dei planetari - come un meccanismo moderno, un potente strumento utilizzato non solo dalla popolazione ma anche dalla scienza e dall'istruzione in altri paesi. Questo articolo discute aspetti della cultura della scuola materiale esplorando fonti ottenute dagli archivi dell'Associazione Brasiliana per l'Educazione e dalla stampa periodica brasiliana, proponendo relazioni ed analisi dell'uso della narrativa della retorica della modernità sull'educazione. I riferimenti teorici a sostegno delle analisi sono legati alla prospettiva degli studi sulla cultura materiale della scuola e sulla storia culturale.

Parole chiave: cultura materiale della scuola, conferenze nazionali sulleducazione, planetario, mostra pedagogica, storia culturale.

\section{INTRODUCTION}

This suggestive image of a planetarium comes from an Italian catalogue that forms part of the collection of the Brazilian Education Association (Associação Brasileira de Educação - ABE) ${ }^{1}$, in Rio de Janeiro. The date of the catalogue, just like a planetarium, can make the researcher go back in time, in this case as far back as 1929. The illustration suggests the beginning or the end of a session in the planetarium in Milan. What other information could this document reveal about a planetarium at that time? What signs could the biography of a documental object bring for research of memory and material culture in the realm of education? Taking into consideration that artifact is an important element of material culture (Meneses $1998,100)$, what could this catalogue indicate? What might be the objectives or the ideas of the intellectuals

\footnotetext{
${ }^{1}$ The Brazilian Education Association (ABE), created in 1924 and based in Rio de Janeiro, played a fundamental role in directing and political organizing of the school education system in Brazil. It took ten years for the Association's collection, later named the Carmem Jordão collection, (in homage to its member Carmem Jordão), to be organize and recovered through the dedicated efforts of another member, Arlette Pinto de Oliveira Silva. ABE has been officially recognized as being of public and social interest since April 2006, thanks to Decree No. 4073, issued by the then President of the Republic, Luiz Inácio Lula da Silva. ABE's current address is Rua México, No. 11, in the center of Rio de Janeiro, and its archives, maintained by funding from private organizations, is particularly important for researchers and scholars interested in learning about the history of the institution. Source: ABE.
}

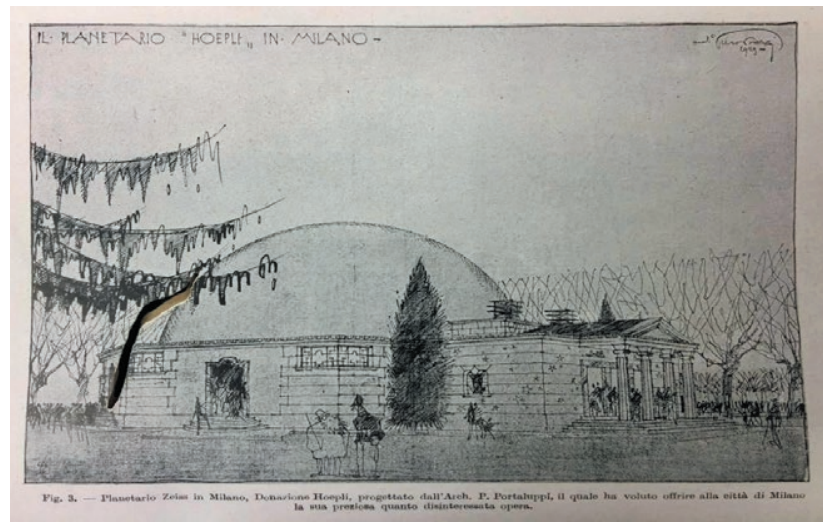

Figure 1. Zeiss Planetarium in Milan, Donation Hoepli, designed by Arch. P. Portaluppi, who wanted to offer the city of Milan his precious and disinterested work. Source: Image taken from the insert entitled A Propósito del Planetario Zeiss, 1929, p. 2, part of the Brazilian Education Association Carmem Jordão Collection (A05-15).

of the Brazilian Education Association when addressing the subject Planetarium?

On Sunday, January $15^{\text {th }} 1928$, three Brazilian periodicals (Gazeta de Notícias, 1928; O Jornal, 1928 and O Imparcial, 1928) $)^{2}$ of the Brazilian capital at that time,

${ }^{2}$ Gazeta de Notícias. Rio de Janeiro. January $15^{\text {th }} 1928$, p. 3, c. IV e V. O Jornal. Rio de Janeiro. January $15^{\text {th }} 1928$, p. 1, c. I. O Imparcial. Rio de Janeiro. January $15^{\text {th }} 1928$, p. 1, c. I 
namely the city of Rio de Janeiro, ran stories on European cities that had gained or were about to gain a Zeiss Planetarium $^{3}$. It should be noted that the representations (Chartier 2002), i.e. the news stories, were published on the same day, in different periodicals but with similar texts. Daily newspapers can become sources, as a support to the senses in order to perceive everyday experiences (Luca 2008). The press presents records of facts and happenings, albeit fragmented, of the social environment. It should also be highlighted that «no document is neutral and always bears the opinion of the person and/or institution that wrote it» (Bacellar 2005, 63). In this sense the press and periodicals, which are not impartial, contain articulations, debates, discussions about the experience of the city, as well as projects for the future, among many other subjects, and it will fall to the historian to look for the answers. In the words of Peter Burke $(2000,205)$ «in order to be a good historian, what is needed is, above all, imagination, perspicacity and sensitivity to discover relevant issues and the right places to find answers to them».

Some time after the newspaper stories, in 1931, a statement by the General Directorate of Information, Statistics and Broadcasting of the Brazilian Ministry of Education and Public Health published in full in the newspaper Diário da Noite, in Rio de Janeiro, on August $6^{\text {th }} 1931$ and in the Jornal do Commercio, on August $7^{\text {th }}$ 1931, appeared to draw the reader's attention to celestial phenomena and astronomy. The text suggests that the subject should be addressed in schools, as highlighted below:

When the day dies and the night enshrouds us with its dark cloak, very few, in a city like Rio de Janeiro, are those who remember to turn their eyes to the firmament and be enraptured by the majesty of the star-studded sky. In large and populous centers, where the orgy of artificial lights dazzles, the tumult of the streets stuns and the strong dynamism of daily toil stunts and dulls sensitivity to the magnificence of nature which only speak to the soul in tranquil and silent settings, no one remembers the wonders that exist above our heads. In truth, to the detriment of education of the people, modern man's disinter-

\footnotetext{
${ }^{3}$ Carl Zeiss is a company with a long tradition. It was founded by Carl Zeiss in 1846 in Jena, Germany, to manufacture precision instruments in mechanics and optics. With effect from 1872, the microscopes made in Jena were built based on scientific calculations, thus producing considerably improved optics. This technological leadership, which ensured the global recognition of the company, is attributed to the physicist and mathematician Ernst Abbe, who became a silent partner of the company in 1876 . Zeiss continues to manufacture lenses and is famous for the technological progress of its products. Further information: https://www.zeiss.com.br/vision-care/pt_br/aboutus/a-historia-da-empresa-de-carl-zeiss.html. (Accessed: January 9, 2019).
}

est in astronomic phenomena is great. While in ancient times people strived to learn about the celestial enigmas, nowadays no one is concerned with this, and children, the object of our greater educational care, leave primary or secondary school knowing little or nothing about our solar system [...]. There is therefore no need to insist as to the convenience of awakening the attention of the masses, and especially that of adolescents, in relation to the celestial phenomena. If the rudimentary nature of the teaching of astronomy in the world's schools might not allow that objective to be achieved, there is a strong need to discover a means by which the people would have a particular interest in contemplating the sky and in such a way to provide this pervading gaze with a little of the magical mysteries of the firmament (Diário da Noite, Rio de Janeiro, August $6^{\text {th }} 1931$, p. 2, c. IV).

The full statement is comprised of three pages and attempts to portray the wonders of astronomy as an important branch of learning, as well as publicizing planetariums as equipment necessary for modern countries. The set of information described in the text offers the historian the possibility of reconstituting some of the vestiges relating to the circulation, representation and assimilation of the theme Planetarium in different places in the world. As described by Chartier $(2002,17)$ "the principal objective of cultural history is to identify the way in which, in different places and at different times, a given social reality is built, conceived, given to interpret». In this way, it can be considered that notes in newspapers, magazines, catalogues, as well as official government statements were providing information or helping the circulation of certain subjects linked to science and the rhetoric of modern education.

The debate to promote the implementation of Brazil's first planetarium occurred in the 1930s and involved the government, intellectuals and educators present in the realm of education in Brazil, or to be more precise, in the Brazilian Education Association (ABE). Founded in 1924, the ABE played a fundamental role in directing and political organizing of the Brazilian school education system, as per its first approved statute: «Statutorily, the Association assigns itself pedagogical objectives "to promote the diffusion and enhancement of education in all branches and to cooperate with all initiatives tending directly or indirectly towards this objective» (Carvalho 1998, 55). The Association operated as a civil society, with voluntary membership. It brought together teachers, intellectuals and people interested in education. Based in Rio de Janeiro, the ABE was represented in several of the country's states, by means of regional chapters. Among its countless activities, it promoted thirteen National Education Conferences between 1927 and 1967. These events were dedicated to debating 
Brazilian education. In parallel to them, pedagogical expositions or activities related to education were also held.

Through its Conferences, surveys, meetings and other activities, during the 1920s and 1930s the ABE debated several subjects regarding education: elementary education, professional education, higher education, schools and families, libraries, statistics, radio, cinema, hygiene and physical education. Given that the 1920s were permeated by the idea of making education a flagship of the building of a modern country (Xavier 1999, 37), it is evident that the ABE played a more active role in the educational reforms proposed at the state and national levels between 1927 and 1935, a period in which, coincidentally, practically one Conference was held per year.

Throughout the entity's golden period of activity, these Conferences functioned as the necessary link between the federal government, state governments and representatives of civil society - teachers, journalists, scientists, religious and political leaders, among others -, constituting an important strategy for the diffusion of ideas and principles dear to certain education organization projects, which, in turn, corresponded to a much broader organization of the State and of Nationality (Mignot, Xavier 2004, $11)$.

In the rhetoric of modern education in Brazil, in this period, it is possible to perceive a field of disputes between different projects. Libânia Xavier (1999) situates the Catholic Church's project, in the 1920s, as being engaged in the struggle for and expansion of spaces in the political, cultural, and educational spheres. During the 1920s, in Brazil as in other parts of the world, there were several debates and initiatives to renew the school system.

Among the proposals coming from different fields of action there is an international movement of the New School that proposed a break with traditional educational structures. Crossing borders, the discourses of the New School arrived in Brazil and were disseminated in the 1920s, in Rio de Janeiro and São Paulo. According to Diana Vidal $(2013,582)$, "If in other countries, the Active School referred to a pedagogical principle, in Brazil in particular it took on a meaning far removed from its meaning in all other countries where it emerged. It brought together not only an educational flagship, but also political investment: the renewal of the public education system».

The scenario of the 1930s is marked by social and political transformations. In Brazil, Getúlio Vargas took up office as interim president. Among his first actions in the field of education he immediately appointed Francis- co Campos and created the Ministry of Education and Public Health (Decree No. 19042, dated November $14^{\text {th }}$ 1930). In a very short space of time Campos signed a set of seven decrees related to Educational Reform, which become known as the Francisco Campos Reform. In 1932, the Manifesto of the Pioneers of New Education ${ }^{4}$ was published, a document addressed to the Government and to the Nation that defended compulsory, secular, and free education for all as a mechanism to democratize education.

Returning to 1931, the reflections of Marta Carvalho (1998) highlight the influence of politics on the $4^{\text {th }}$ National Education Conference and also on the ABE itself, which promoted the event. The Ministry of Education took an active part in promoting the Conference and on December $4^{\text {th }} 1931$ it issued a press statement which praised the "valuable cooperation that the Conference could provide to the government» (Carvalho 1998, 376). Carvalho further suggests that the State had expectations that the Conference would formulate the «new directives» that it was «seeking to stamp on Brazilian activities in the field of education» (Carvalho 1998, 380).

In 1931, the $4^{\text {th }}$ Conference debated the theme «The Great Directives of Popular Education», chaired by Fernando Magalhães ${ }^{5}$, president of the $\mathrm{ABE}$, with the pres-

${ }^{4}$ The Manifesto of the Pioneers of New Education was written by Fernando de Azevedo and signed by the following educators: Afranio Peixoto, Sampaio Doria, Anísio Teixeira, Lourenço Filho, Roquete Pinto, J. G. Frota Pessoa, Julio de Mesquita Filho, Raul Briquet, Mário Casanta, C. Delgado de Carvalho, Ferreira de Almeida Júnior, J.P Fontenelle, Roldão Lopes de Barros, Noemy M. da Silveira, Hermes Lima, Attilio Vivacqua, Francisco Venâncio Filho, Paulo Maranhão, Cecília Meireles, Edgar Sussekind de Mendonça, Àlvaro Alberto, Garcia de Rezende, Nóbrega da Cunha, Paschoal Leme and Raul Gomes (Filho 2002, 19).

${ }^{5}$ According to the website https://www.ihgb.org.br/ (Accessed: January 9, 2019) of the Brazilian Institute of History and Geography (IHGB), Fernando Magalhães was born in Rio de Janeiro on February $18^{\text {th }} 1878$ and died there on January $10^{\text {th }} 1944$. He was the son of Antônio Joaquim Ribeiro Magalhães and Deolinda Magalhães. He studied humanities at Colégio Pedro II, and obtained a bachelor's degree in Sciences and Arts (1893). He trained at the Rio de Janeiro Faculty of Medicine where he obtained a Ph.D. in 1899. He was a professor of clinical obstetrics at the same Faculty, Director of the Rio de Janeiro Maternity Hospital, member of the National Education Council, Director of the Faculty of Medicine, Chancellor of the University of Rio de Janeiro, Director of the Pro-Matre Hospital, Consultant of the Beneficencia Portuguesa Hospital, Chairman of the $1^{\text {st }}$ and $4^{\text {th }}$ National Education Conferences and Delegate of the State of Rio de Janeiro at the 1933 Constituent Assembly. He was a member of the Brazilian Academy of Obstetrics and Gynecology (President), a member of the Brazilian Medical Trade Union (President), a member of the Brazilian Medical Association (President in 1932), a member of the ABE (President in 1926, 1927, 1930 and 1931), a member of the National Academy of Medicine, a member of the Brazilian Academy of Arts (President in 1929, 1931 and 1932 and Secretary-General in 1934), a member of the Society of Medicine and Surgery (President in 1919, 1920, 1922, 1923 and 1928), a member of the Brazilian League of Mental Hygiene (Honorary Pres- 
ence of the Head of the Interim Government, Getúlio Vargas, and the Minister of Education and Health, Francisco Campos. As such, documents found at the Association indicate more specifically that during the course of 1931, certain dealings and negotiations took place between the Carl Zeiss company and the ABE, during the organization of the $4^{\text {th }}$ National Education Conference and the Pedagogy Exposition, with the aim of implementing the first Zeiss Planetarium in South America, the wonderful contemporary instrument capable of simulating the sky at any time.

Considering the subject Planetarium as part of this debate, implies thinking about how this invention could be a mechanism or a support for exhibiting a view of the world and of modern education. It is possible to perceive in Brazilian education that the discourse of modernity aligned with the word progress and valuing of novelty is present in several biographies. Rosa Fátima de Souza (2000) describes that many models, theses and strategies developed in so-called civilized countries were debated in Brazil in the realm of politics and pedagogy.

(...) teaching methods, expanding programs by including new disciplines, textbooks and manuals, student classification, distribution of contents and use of time, furniture, school material, study certificates, architecture, teacher training, school discipline. A variety of mechanisms enabled these ideas and models to circulate: the Universal Expositions, teaching congresses, official reports prepared by ministers and teaching inspectors, books, articles, newspapers and specialized journals published on education (Souza 2000, 3).

What were the intentions of the Brazilian Education Association in debating the acquisition of a Planetarium in time for the $4^{\text {th }}$ National Education Conference? To strengthen instruments and equipment for national education of teachers and students? To gain visibility and legitimacy as a group of intellectuals devoted to Brazilian education? An important fact to be evaluated is that by the onset of the Second World War there were around 25 planetariums worldwide (Steffani e Vieira 2013).

Another news item published by the Jornal do Commercio newspaper corroborates the documents highlighted above by informing that the Executive Commission of the $4^{\text {th }}$ National Education Conference was work-

ident), a member of the National Defense League, the American College of Surgeons, the Paris Société d'Obstétrique, the Lisbon Academy of Sciences, the Equator Society of Medicine and Surgery, the São Paulo Academy of Medicine, the Medicine Societies of Pernambuco, Paraíba and São Paulo, the Medicine Societies of Campos and Petrópolis, the Academies of Medicine of Mexico, Buenos Aires and Madrid, the Buenos Aires Obstetrics Society, the Argentinean Medical Association, and the Academic Society of Medicine and Surgery. ing to make the event a space for dialoguing about issues concerning progress with teaching in Brazil.

The Executive Commission of the Conference has taken decisions that are undeniably correct and result in achievements of a high cultural and educational purpose. Just to mention the most important, it suffices to remember the planned joint visits of conference-goers to several scientific and educational institutions, including The Viçosa Agricultural and Veterinary Higher Education School, a model technical teaching establishment, the launching of the idea to set up as soon as possible the Rio de Janeiro Planetarium, destined to be the first in South America, the initiative for children's playgrounds, which is due to be inaugurated precisely on October $12^{\text {th }}$ in a central and picturesque part of the city in Praia do Russell; and finally the organization at the Conference venue of an exposition of school materials and books (Jornal do Commercio, Rio de Janeiro, August $20^{\text {th }} 1931$, p. 3, c. IV).

From the above text it can be inferred that apart from the debates on themes that had taken place at the $1^{\text {st }}, 2^{\text {nd }}$ and $3^{\text {rd }}$ Conferences, the intention was also to schedule a repertoire of actions for the $4^{\text {th }}$ Conference. This repertoire included pedagogical and/or school expositions, visits to schools considered to be a reference, exhibitions of objects and artifacts and presentations of choral singing and physical exercises in general. All these activities, presented with different apparel, can be considered as exhibition devices, with the idea of giving visibility to that which was a reference at that time. Some of these ideas were unprecedented, such as the setting up of the country's first planetarium, for instance. It is also appropriate to remember that an interim government had recently taken up office, which needed a showcase to give visibility to its actions related to education and that the $4^{\text {th }}$ Conference would be an opportune space and moment for the Minister to present the plans that could make effective the Reform decreed by the government.

PLANETARIUM, EDUCATIONAL FILMS AND

EQUIPMENT: A PROPOSAL FOR THE SCHOOL MATERIAL EXPOSITION AD A SIDE EVENT TO THE $4^{\mathrm{TH}}$ NATIONAL EDUCATION CONFERENCE

In the archives of the Brazilian Education Association, in the sources ${ }^{6}$ relating to the $4^{\text {th }}$ National Educa-

\footnotetext{
6The letters were found at the Brazilian Education Association in folder A05-15 of the Carmem Jordão collection, in relation to the $4^{\text {th }}$ National Education Conference, during the search for sources carried out in July 2018. The folder contained correspondence sent and received, the insert and material publicizing the Zeiss Planetarium in Italian and German, a
} 
tion Conference, four letters between the Carl Zeiss company and the $\mathrm{ABE}$ point to part of the negotiations for acquiring the planetarium. The documents found there included: a copy of the statement by the General Directorate of Information, Statistics and Broadcasting of the Brazilian Ministry of Education, published in full in some newspapers in 1931; a 12-page printed document written in Italian containing technical information on the Zeiss Planetarium proposal; a 16-page printed document written in German and one handwritten aidemémoire of a debate or meeting between $\mathrm{ABE}$ members as transcribed below:

Brazilian Education Association - Notes 4th National Education Conference.

1. Dr. Teixeira de Freitas stated that the planetarium costs around 1000 contos de reis and that the Zeiss Company takes around 10 months to assemble it.

2. Ask the Mayor to allow the Palácio das Festas to be used to hold the Conference and the school books and materials Exposition. Fernando de Magalhães is to make the request to the Mayor.

3. Book on the $4^{\text {th }}$ Education Week is the responsibility of Mr. Barbosa de Oliveira, who asked Fern. Magalhães and Backeuser for articles 3.8.31. The publication has been authorized by the Ministry of the National Press.

4. Ome Bupe Report, submitted to Minas Government, and plan for kiosks for Children's Libraries delivered to the Ministry of Education. Dr. Teixeira de Freitas is responsible for them. (Handwritten note, $\mathrm{ABE}$ archives).

The text lists four points related to the organization of the event, like a sort of aide-mémoire of a meeting or probably a summary of actions to be given to the Organizing Commission. The handwritten note discolored by time provides clues as to the debate within the $\mathrm{ABE}$ on the attempt to set up Brazil's first Planetarium during the Conference. Notes 1, 2, 3 and 4 appear to list the actions decided on and those responsible for doing them in order to turn the plans into reality. Another interesting point is that the Conference organizers did not have enough time, even though the event was organized several months beforehand. According to the dates on which the letters were written and the date scheduled for the $4^{\text {th }}$ Conference, everything would have to be defined in space of four to five months. According to item 1 of the notes, the Carl Zeiss company would need at least ten months to assemble the Planetarium. However, nothing prevents the word "assemble" from being a reference to building and assembling. Perhaps, with resources and

handwritten note and a copy of the statement by the General Directorate of Information, Statistics and Broadcasting of the Brazilian Ministry of Education, among other documents.

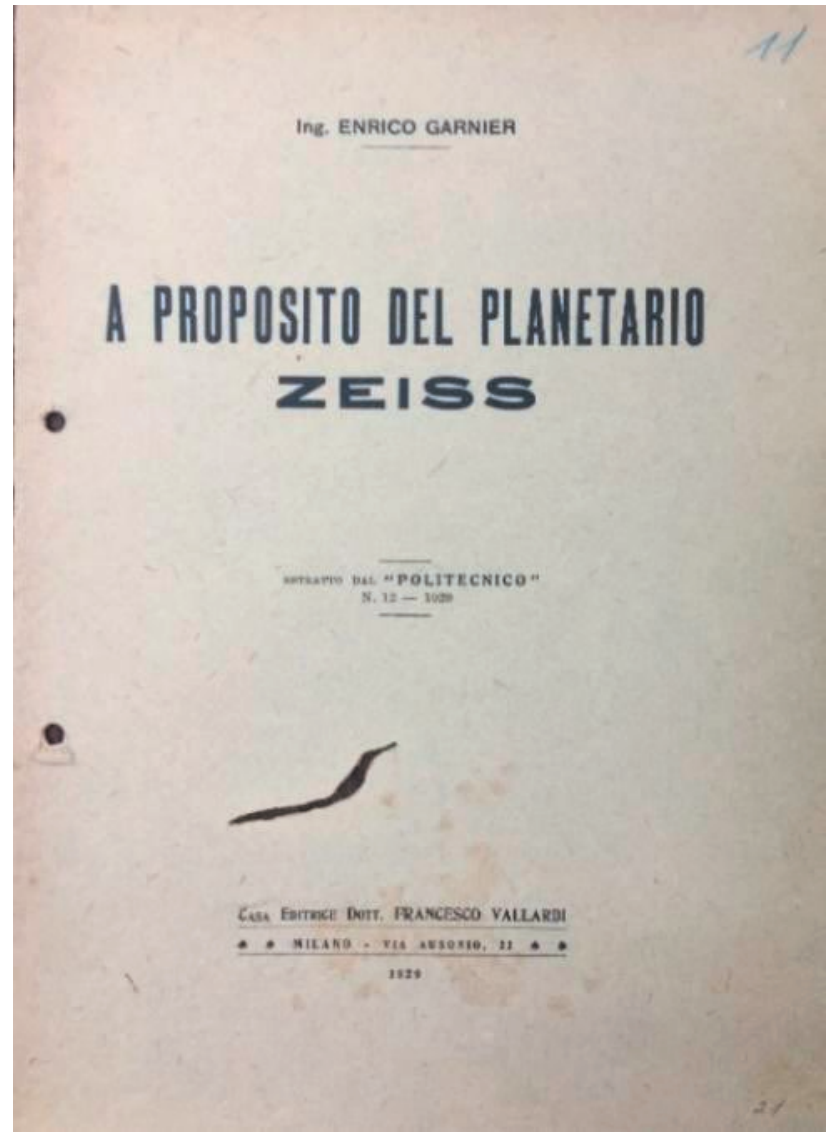

Figure 2. Cover of the Zeiss Planetarium insert (Source: Carmem Jordão Collection, Brazilian Education Association -ABE).

political strength, it might have been possible to install the Zeiss Planetarium in less time, or purchase another planetarium the sale of which had not yet been agreed on. Another interesting esthetic detail are the marks time has left on the documents.

The letters found at the $\mathrm{ABE}$ archives are addressed to $\mathrm{ABE}$, to Fernando Magalhães as Chairman of the Organizing Commission of the $4^{\text {th }}$ National Education Conference and to Miss Eva Louis Hyde $\mathrm{H}^{7}$ of the Bennett College ${ }^{8}$. In addition to the information relating to the

${ }^{7}$ Miss Eva Louise Hyde was born in 1885 and died in 1981. She ran Bennett College from 1925 to 1952 . Chancellor was the title given at the time to the Headmistress of Bennett College. She was a Methodist Church missionary and an educator for 40 years in Brazil. She was a co-founder and member of several educational ecumenical groups in Brazil. She was the only foreign citizen to be awarded the National Order of Merit, as an Officer of the Order, on December $1^{\text {st }} 1953$. Additional information at: http://cogeime.org.br/miss-eva-louise-hyde/ (Accessed: January 9, 2019).

${ }^{8}$ The Bennett Methodist College was inaugurated in 1920 with lessons for 50 primary school children. Within the first year this number doubled and enrollment had to be refused because of low capacity to 


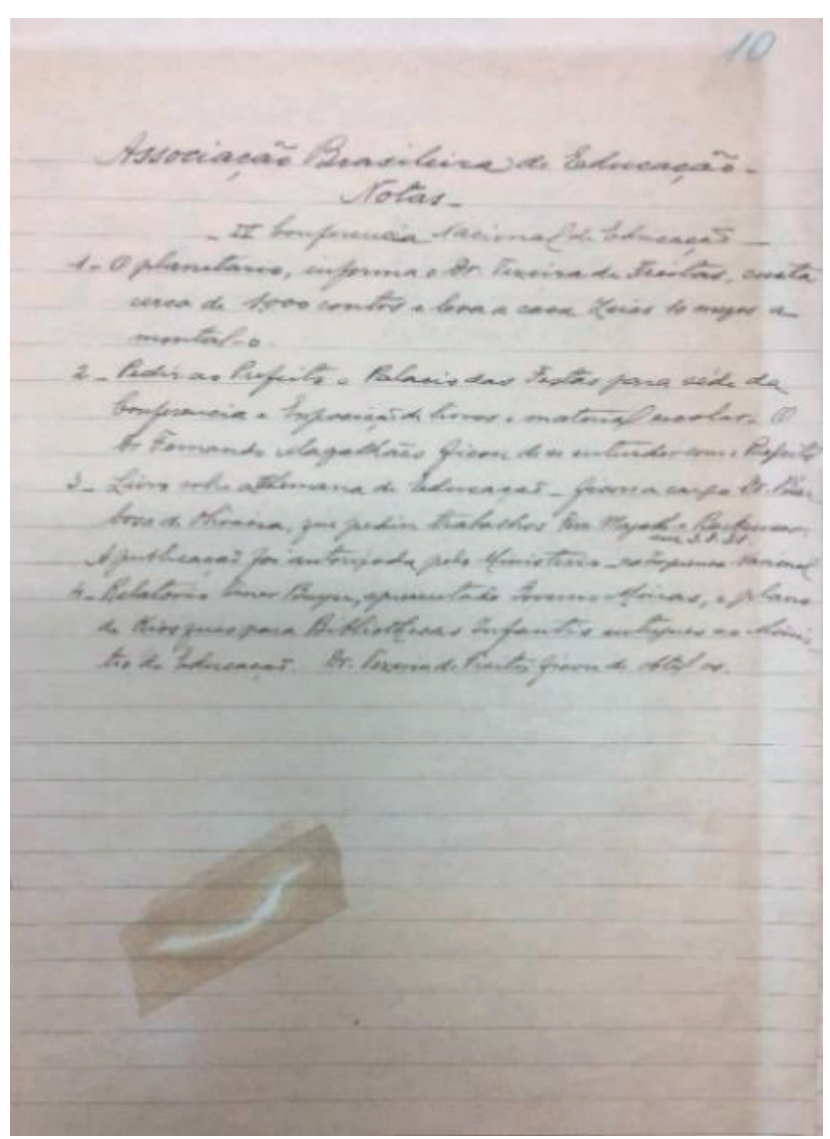

Figure 3. Handwritten note filed together with the insert (Source: Carmem Jordão Collection, Brazilian Education Association -ABE).

Zeiss Planetarium, the Zeiss company offered educational films prepared by Universum Film Aktien Gesellschaft or Universum Film AG (UFA) and other devices to form part of the School Material Exposition side event at the $4^{\text {th }}$ National Education Conference. UFA was Germany's most important cinema studio network. Between 1917 and 1945, UFA was a leading company of the sector and a direct competitor of Hollywood.

Table 01 below illustrates the subjects of the correspondence between the $\mathrm{ABE}$ and the Carl Zeiss company. The documents point to attempts to prepare the Exposition in the best possible way, as well as signs of negotiations to purchase a noteworthy invention in terms of both its purpose and its popularity.

The Zeiss Planetarium was able to reproduce the sun and other planets in an artificial sky. It is an educational apparatus with multifaceted potentiality: it reproduces the sky, latitude, sun, moon, planets at any point

accommodate boarding students. Additional information at: http://bennett.br/centrouniversitario/institucional/historia (Accessed: January 9, 2019). in time, a sort of time machine. The sessions projected in the dome are the great attraction of the planetarium. With the aid of projectors conceived to simulate stars in the sky, the sessions can intersperse educational and entertainment activities. The sessions can be live and conducted by a professional called a planetarist who provides scientific knowledge to the audience. The sessions can also be recorded. In the advertising insert in Italian found at the $\mathrm{ABE}$ and entitled A Proposito del Planetário Zeiss, estratto dal "Politecnico" N.12 - 1929, by engineer Enrico Garnier, a variety of technical information, images and possibilities of using the planetarium for science and education are offered to interested readers:

A significant benefit of the Planetarium is that of awakening renewed interest in scientific literature on popular astronomy; not excessively rich but nevertheless including a good number of clear informative features, among which it appears to us not to be irreverent to put in first place the very clear "Dialogues" of Galileo; also noteworthy are the delightful "Entretiens" by Fontenelle, the fundamental "Astronomie Populaire" by François Arago, the countless publications of Abbot Moureaux, the vast philosophic-scientific production of Flammarion, whose "Astronomie Populaire", jointly with the "Les Etoiles et curiosités $d u$ Ciel" are even today the most complete, attractive and suggestive publications on the subject, the hugely original works of Filopanti, the pages on popular astronomy by G. Schiapparelli, the substantial work of Cardinal Maffi and that recently published by Brioschi. And to us the presumption appears legitimate that the rise of the Planetarium is to determine a more exuberant development of the "Italian Astronomy Society", destined to awaken and disseminate to all cultured people, through conferences and the publication of bulletins, love for the science of the sky (Zeiss Planetarium Insert 1929, 10).

Part of the literature listed above in the Zeiss insert, which publicizes celestial knowledge over time, helps us to think about how the world is represented. Based on the statements of Chartier $(2002,17)$ «the representation, assimilation and the way of interpreting» the world undergo processes that involve social, political and cultural practices and can produce diverse interpretations in different social groups. Mankind being enchanted by the stars and questioning about the universe is not something new. Planetariums and devices aiming to reproduce the star-studded sky, the moon, the sun, the planets and their movements have existed since Archimedes.

The first Planetarium was built by Archimedes in about 20 B.C. and is known to have represented the movements of the planets, the Sun and the Moon, eclipses of the sun and the moon. It is assumed that the entire system was 
Table 1. Summary of the letters between the Carl Zeiss company and the ABE.

Documents

All the letters are written on Carl Zeiss headed Subjects

paper

1. Carl Zeiss letter to ABE, addressed to

Fernando Magalhães, the then Chairman of the Organizing Commission of the $4^{\text {th }}$

National Education Conference.

2. Carl Zeiss letter to ABE, addressed to Fernando Magalhães, the then Chairman of the Organizing Commission of the $4^{\text {th }}$ National Education Conference.

3. Carl Zeiss letter to Miss Eva Louis Hyde, Bennett College

4. Carl Zeiss letter to ABE, addressed to the Chairman of the Organizing Commission of the $4^{\text {th }}$ National Education Conference.
Synthesis of the contents of each letter

Date

Thanks for the invitation to take part in the $4^{\text {th }}$ National Education Conference and question about its venue.

$20 / 08 / 1931$

School Material Exposition as a side event to the $4^{\text {th }}$ National Education Conference. Offer of German educational films made by UFA (kulturfilms) about astronomy, botany, zoology etc. Mr Luiz Grentner was indicated for the negotiations.

Lecture by Mr. Robert Lehr at the $4^{\text {th }}$ National Education Conference. Offer of microscopes (for botany, medicine and minerology); prepared microscope slides with instruction manual, projection devices (episcope, diascope and microscope); apparatus for demonstrating physics experiments, apparatus for teaching topography and astronomy at the school. It also details the kind of electricity current and the conditions needed for the exposition room.

Negotiations on purchasing the Zeiss Planetarium, at a minimum price of 72,000 dollars, and methods of payment. It also suggests that the Conference Organizing Commission should attempt to do fundraising to pay for the planetarium. The letter informs that the Zeiss company only builds planetariums after receiving certain financial guarantees, but that due to the economic crisis faced by Germany, the company wishes to demonstrate goodwill in assisting Brazilian scientists and scholars.

(Source: Documents retrieved from the Carmem Jordão Collection at the Brazilian Education Association-A05-15).

placed inside a hollow sphere in which the stars were represented, which turned driven by water and the inside of which could be seen through an opening. In the Middle Ages, the Arabs built Planetariums and celestial globes, the most beautiful of which is to be found in Dresden (Martins apud Barrio 2002, 34).

In Munich in 1913, with the aim of encouraging astronomy, studies began regarding building a device that artificially represented the universe. After ten years of research and several experiments, Dr. Walther Bauersfeld (1923) presented the Zeiss Planetarium, made in Germany. The invention was a huge challenge for engineering of the time. The first presentations took place in Jena, where the Zeiss company is based, and then in Munich. «80,000 visitors have come to see the impressive astronomical show at the Yena dome», Friar Pedro Sinzig ${ }^{9}$ wrote in the Jornal do Brasil newspaper in 1927.

\footnotetext{
${ }^{9}$ Pedro Sinzig was born on January $29^{\text {th }} 1876$ in Linz am Rhine (Germany) and died on December $8^{\text {th }} 1952$ in Düsseldorf, Germany. His mortal remains lie in the São João Batista Cemetery, in Botafogo in Rio de Janeiro. Friar Pedro studied at the Harreveld College in the Netherlands. When he was 16 years old he joined the Franciscan Order. In 1893, when he was still a novice, he came to Brazil. He became a naturalized Brazilian on February $9^{\text {th }} 1898$, on the eve of his ordination as a priest in Bahia. He belonged to the first group of German Franciscans who restored the Province. He was an exemplary friar, as he
}

Under any circumstances, there are two things that makes the Planetarium, with its perfect illusion, preferable for forming intelligence: firstly, it enables the teacher to point to the sky, not with a ruler as is done with maps, but with a ray of light, to indicate the stars that he wants to describe and to trace the open routes in the firmament. In this way the teacher shows the groups known since the most ancient times, whether this be the entire family of the Southern Cross, or other less well-known groups. He shows the Pole Star, Venus, Mars etc... etc... and then moves on to the Planetarium's principal advantage: silently, without the slightest noise being heard from the extremely complex apparatus, the firmament begins to turn, completing in 4 minutes the process that in nature

fought in many domains for the glory of God and the good of people's souls, for the development of culture and art; he was an advocate of the Christian ideal in the press, in the tribune, in the cinema, in historical research. At 76 years old he traveled to Germany and died there shortly afterwards. Friar Pedro was an innate journalist. In April 1902, he founded the Cruzeiro do Sul, in Lages, SC, which contrasted both in terms of ideas and comments with the other two local newspapers, one of which served as a voice for politics, while the other belonged to the Freemasons. Later, in Petrópolis, he founded the Centro da Boa Imprensa (1910), providing new guidance to the Vozes de Petrópolis magazine, which he edited for 12 years (1908-1920). A distinctive commentator, his pen produced the most diverse literary genres, from religious works to romance and novels, from history and geography to art. Source: http://www.luteranos.com.br/textos/pedro-sinzig-1876-1952 (Accessed: January 9, 2019). 
takes 24 hours. The sun begins to rise, pale so as not to outshine the natural glow of the stars. It rises more and more until it disappears in the firmament. It does not take long for us to live a day in just 4 minutes...everything in proportion with reality. In this way the audience watches a spectacle that it could never do so in nature, because during the day the sun does not allow one to observe the stars and their movement (Jornal do Brasil, Rio de Janeiro, April $9^{\text {th }} 1927,14$, c. II).

The rhetoric of the wonders of science and of the technique employed in the Planetarium was announced by the press as a multifaceted invention that could be used by teachers, students and the population that watched the spectacle. An example of this is found in edition 52 of the magazine entitled O Cruzeiro, which provides an elucidating and complete text about the invention, how it works, places where planetariums are located, as well as their cultural and scientific importance for the world. The text, signed by Mary Emily Huggins ${ }^{10}$ in a special feature for the magazine, indicates that the invention was beginning to spread around the world. "Now there are planetariums in 11 Germany cities, 2 in Italy, 2 in the United States of America, 1 in Austria, 1 in Russia and 1 in Sweden, despite their relatively high price» (O Cruzeiro 1931, 27). Indeed, the invention was in circulation in various parts of the world and although it was costly, in a short space of time, big cities purchased Planetariums in the name of science and as an apparatus to be used to educate about astronomy. In the case of Brazil, the text also suggests that in order to avoid additional expenditure, the dome of the Palácio das Festas building in Rio de Janeiro would be a way out. The planetarium room could be used for conferences, concerts, debates and for projecting films to develop the intellect of students. The magazine article also informs that many planetariums were acquired through private donations, such as the Milan Planetarium which was donated by Ulrico Hoepli, the Philadelphia Planetarium donated by S.S Fels and the Munich Planetarium donated by the Carl Zeiss company.

Besides offering the Zeiss Planetarium at a minimum price of 72,000 dollars, one of the Carl Zeiss letters to the ABE, dated December $10^{\text {th }} 1931$ and addressed to the Chairman of the Organizing Commission of the $4^{\text {th }}$ National Education Conference, corroborates the idea of seeking funds to pay for the invention, as can be seen here:

\footnotetext{
${ }^{10}$ Mary Emily Huggins was an officer of the General Directorate of Information, Statistics and Broadcasting of the Brazilian Ministry of Education and Public Health in 1934. Additional information is available at the Digital Newspaper Library: http://memoria.bn.br/DocReader/313394/112347 (Accessed: January 9, 2019).
}

(...) By means of some form of guarantee and interest charges, we could perhaps agree on other proposals for extending deadlines. It can be seen, therefore, that the Carl Zeiss company, in addition to proposing a minimum price, is inclined to consider any reasonable proposal on the method of payment. Moreover, if this Commission wishes to make moves to raise funds from States, Municipalities and Private concerns to purchase the Zeiss Planetarium to be incorporated into its assets for the purposes of university extension, this subsidiary offers its services to assist with the respective advertising, so that once it is authorized to do so (Letter 03, Table of sources).

Based on this letter and the other communications mentioned above, it can be deduced that idea of having a Zeiss Planetarium in Brazil was under debate. While on the one hand the European and American nations were investing in the invention, Brazil was also looking for a way to have a planetarium and stand out among the South American countries. Returning to the statement of the General Directorate of Information, Statistics and Broadcasting of the Brazilian Ministry of Education and Public Health with which this article begins, another excerpt illustrates the debate:

This is then an initiative and an example that need to be imitated in the Brazilian Capital, giving Brazil primacy, among the South American countries, as being owner of a fine Planetarium. Building the Planetarium, in this city, is a subject already raised by professor Agache, who wanted it to be built in the planned Praça Monumental, the entrance gate to the city, and it would appear that the journalist Assis Chateaubriand was also interested in it (Diário da Noite, Rio de Janeiro, August $6^{\text {th }} 1931,2$, c. IV).

However, the building of the desired, planned and debated scientific equipment in the 1930s, as per the documents consulted at the ABE, was not successful. During our research it was not possible to identify how this debate ended. One apparent reason could be related to the high cost of the equipment ${ }^{11}$. Brazil's first planetarium was only effectively brought into operation in 1957, in São Paulo, thanks to the efforts of the Amateur

\footnotetext{
${ }^{11}$ Regarding the cost of the planetarium, a letter sent by the Carl Zeiss company to the $\mathrm{ABE}$, addressed to the President of the Organizing Committee of the IV National Education Conference (NCE), indicates a minimum budget of 72,000 dollars, the same price as the Zeiss Planetarium installed in Jena, Germany. There is information about payment options. It also suggests that the Organizing Committee of the IV Conference should do fundraising to pay for the planetarium. It also informs that the Carl Zeiss company will only build the planetarium after receiving certain financial guarantees, but due to the crisis that Germany is facing, the company is keen to show goodwill in assisting Brazilian scientists and scholars. Source: Brazilian Education Association - ABE. Diverse documents relating to the IV NCE. FOLDER A0515 , letter dated 10/12/1931.
} 
Astronomers' Association of São Paulo (AAA-SP), led by professor Aristóteles Orsini ${ }^{12}$, who was the planetarium's first director. According to the article by the chemical engineer and amateur astronomer, Tasso Augusto Napoleão $(2013,464)$, in 1959 the AAA-SP already had more than one thousand members and operated the Planetarium on a free of charge and voluntary basis, distributing entrance tickets, seeing to the musical part and auxiliary projections. Between its inauguration in 1957 and 1959, there were 1,201 presentations watched by 339,487 people. The Professor Aristóteles Orsini Planetarium is still in operation today and is administered by the São Paulo City Government, through its Open Environment University. The building is an important historical, scientific and cultural legacy, listed by the São Paulo City Historical, Cultural and Environmental Heritage Listing and Preservation Council, as well as by the São Paulo State Historical, Archeological, Artistic and Touristic Heritage Defense Council.

\section{FINAL CONSIDERATIONS}

For the time being, the only way to go back in time is to put the clock back during a session projected on the dome of a planetarium. Other than this, in order to shed light on past happenings, the historian needs to seek sources that hold vestiges of history. Bloch (2002, 69) emphasizes the requirement of an in-depth analysis of documents about bygone facts that exist and persist and bear witness of given periods in time; "In relation to bygone times, we can therefore only capture them through the words of witnesses (...) this requires, however, that they be sensitively nuanced». From the analysis

\footnotetext{
12 Aristoteles Orsini (1910-1998) was born in Avaré, in the interior region of São Paulo state, and moved to São Paulo City in 1922. He graduated in Medicine at the University of São Paulo in 1933 and became a Ph.D. in 1934, in addition to studying Physics and Mathematics at the same University. He was a lecturer at the São Paulo School of Medicine and at the University of São Paulo Faculty of Pharmacy and Dentistry where, in 1947, he became a Full Professor. Later he received the esteemed title of Emeritus Professor of the University of São Paulo (Varella, 2005). He worked as a doctor and a university professor and was a highly regarded amateur astronomer. His name is closely linked to the Amateur Astronomers' Association of São Paulo (AAA-SP), of which he was one of the founders and a director for many years, as well as the Ibirapuera Planetarium (Brazil's first) and the Municipal School of Astrophysics, both located in São Paulo City. Orsini was the leading figure responsible for these two institutions being set up (in January 1957 and January 1961, respectively); he remained the director of both of them until 1980. Today, both institutions deservingly bear the name Orsini. The AAA-SP was created in 1949 within the Faculty of Pharmacy. Additional information is available at: http://site.mast.br/pdf_volume_2/dos_tempos_imperio_observatorios_roboticos.pdf (Accessed: January 9, 2019).
}

of these documents, traces can be found of the attempt, albeit frustrated, of the intellectuals of the ABE to purchase the Zeiss Planetarium in the 1930s to form part of the country's educational sphere. The empirical basis, investigated in the Brazilian press, has helped to compose a picture to assist with understanding the debates and representations (Chartier 2002) with regard to subject of the planetarium. Evidence points to the occurrence of the debate and the circulation of the idea of setting up a planetarium among the intellectuals of the Brazilian Education Association, the press and the government. Members of these realms promoted the debate and the circulation of the idea that acquiring a planetarium would be important for the "new perspectives" that education was taking in the 1930s. Attempts to publicize the invention and how its utility could be directed towards science and education can be perceived in the Official Education Ministry Statement which was published in the capital's newspapers. Other notes in periodicals also looked at parts of this debate and promoted the idea of the planetarium, disseminating narratives of how and when other cities and countries had mobilized themselves to acquire planetariums.

Also according to the documental sources, letters and catalogues from the ABE archives, used to produce this dialogue, the intention existed to present new devices and elements to comprise the School Material Exposition as a side event to the $4^{\text {th }}$ National Education Conference. Moreover, if the ABE intellectuals, with the support of the government, had achieved the feat of effectively setting up the Planetarium in 1931, they would have offered an enduring educational space that could have been used for teacher training, as well as by students and by the population in general. All tied to the rhetoric of modern education.

The main challenge of a researcher is to circumscribe their problem. With regard to historic observation, Bloch $(2002,81)$ states that there needs to be at least a "varnish of all the main techniques of their trade. Even if only to know how to assess beforehand the strength of the tool and difficulties in handling it». This task establishes itself during research by undertaking some methodological procedures: finding the sources; delimiting the time period; defining the study criteria; and studying the literature and research related to the theme, among other procedures. Material vestiges are instruments of great importance for doing searches. At times, the researcher comes across other subjects related to the context, that were part of history, but were not successful.

When studying school writing practices at the end of the $19^{\text {th }}$ century, Diana Vidal (2005) analyzes a failed 
innovation as an historic object that took place in France. Moreover, she points out that interest in failure is not a characteristic of the majority of studies of history. According to her, in relation to school, successful innovations have managed to subsist in historical time, and are permanently investigated because they are perceived as part of the foundations of the evolution of teaching. The study of projects that failed and left no trails in this memory is, in general, abandoned (Vidal 2005, 131).

These documents concerning a frustrated action represented in letters, catalogues, budgets, press statements and notes are also part of history. Writing about a failed scientific debate that took place in the 1930s, invites one to retie the threads of this plot and explore the paths taken by the Brazilian Education Association, in the sense of reflecting on the construction of the Brazilian school. The debate on the planetarium also assists with the perception of the circulation of texts and of practices that occurred elsewhere as being models for Brazil.

\section{BIBLIOGRAPHICAL REFERENCES}

Bacellar, Carlos. 2005. "Fontes documentais: uso e mau uso dos arquivos." In Fontes históricas, edited by Carla B. Pinski, 23-79. São Paulo: Contexto.

Barrio, Juan Bernardino Marques. 2002. El Planetário: Um recurso Didáctico para la Enseñanza de la Astronomia. PhD diss., Universidad de Valladolid, Facultad de Educación y Trabajo Social Departamento de Didáctica de las Ciencias Experimentales y Geodinâmica.

Burke, Peter. 1992. "Abertura: a nova história, seu passado e seu futuro." In A escrita da história: novas perspectivas, edited by Peter Burke, 7-32. São Paulo: Editora UNESP.

Burke, Peter. 2000. "Peter Burke”. In As muitas faces da história: nove entrevistas, edited by Maria Lucia Pallares-Burke, 185-323. São Paulo: Editora UNESP.

Bloch, Marc. 2002. Apologia da história ou o ofício do historiador. Rio de Janeiro: Zahar.

Chartier, Roger. 1991. "O mundo como representação." Estudos avançados, São Paulo, v. 5, 11: 173-191.

Chartier, Roger. 2002. A História Cultural: entre práticas e representações. $2^{\text {a }}$ Ed. Portugal: DIFEL.

Carvalho, Marta Maria Chagas de. 1998. Molde nacional e fôrma cívica: higiene, moral e trabalho no projeto da associação brasileira de educação (1924-1931). Bragança Paulista: EDUSF.

Carvalho, Marta Maria Chagas de. 2003. A escola e a república e outros ensaios. Bragança Paulista: EDUSF.
Filho, Ernesto de Souza Freire. A trajetória da Associação Brasileira de Educação (1924-2001). Publicação da ABE. Editora do Educador. Grupo Folha Dirigida.2002.: 16-28.

Gaspar da Silva, Vera Lucia, e Gizele de Souza. 2016. Objetos de utilidade prática para o ensino elementar: museus pedagógicos e escolares em debate. Br/hotsite_anais_ivspct_2/pdf_02/16\%20\%2011\%20trabalho\%20veragaspar\%20e\%20gizelesouza.pdf. Acessed: May 13, 2018.

Julia, Dominique. 2001. "A cultura escolar como objeto histórico." Revista Brasileira de História da Educação 1: 9-43.

Kuhlmann Júnior, Moysés. 2001. As grandes festas didáticas: a educação brasileira e as exposições internacionais (1862/1922). São Paulo: USF/CDAPH.

Luca, Tânia Regina de. 2008. "História dos, nos e por meio de periódicos." In Fontes históricas, edited by Carla B. Pinski, 111-153. São Paulo: Contexto.

Martins, Cláudio Souza. 2009. O planetário: espaço educativo não formal qualificando professores da segunda fase do ensino fundamental para o ensino formal Goiânia/GO, Mestrado: Universidade Federal de Goiás.

Meneses, Ulpiano T. Bezerra de. 1998. "Memória e cultura material: documentos pessoais no espaço público." Estudos históricos 11, 21: 89-104.

Napoleão, Tasso Augusto. 2013. Dos tempos do império aos observatórios robóticos. http://site.mast.br/ pdf_volume_2/dos_tempos_imperio_observatorios_ roboticos.pdf. Accessed: January 3, 2019.

Pesavento, Sandra Jatahy. 1997. Exposições universais: espetáculos da modernidade do século XIX. São Paulo: Editora Hucitec.

Souza, Rosa Fátima de. 2000. "Inovação educacional no século XIX: a construção do currículo da escola primária no Brasil.” Cadernos Cedes 20, 51: 9-28. http://dx.doi.org/10.1590/s0101-32622000000200002. (Accessed: January 9, 2019).

Souza, Rosa Fátima de. 2007. "História da cultura material escolar: um balanço inicial.” In Culturas escolares, saberes e práticas educativas: itinerários históricos, edited by Marcus Levy Bencostta, 163-169. São Paulo: Cortez.

Vidal, Diana Gonçalves. 2005. Culturas Escolares: estudo sobre práticas de leitura e escrita na escola pública primária (Brasil e França, final do século XIX). Campinas, SP: Autores Associados.

Vidal, Diana Gonçalves. 2013. "80 anos do Manifesto dos Pioneiros da Educação Nova: questões para debate." Educaçao e Pesquisa São Paulo, v. 39, n. 3, 577-588, jul./set. 2013. http://www.scielo.br/pdf/ep/v39n3/ aop1177.pdf. Accessed on 15/06/2020. 
Vidal, Diana Gonçalves. 2008. "Lá vem o Bonde das Normalistas... Uma incursão pelo cotidiano escolar do Instituto de Educação do Rio de Janeiro na década de 1930." In: As Escolas normais no Brasil: do império à república, edited by Araujo. J. C. S; Freitas, G. B. F.; LOPES. A. P. 233-247. Campinas - SP: Editora Alínea.

Mignot, Ana Chrystina, e Xavier, Libânia Nacif. "Apresentação." In Páginas da história: notícias da II Conferência Nacional de Educação da ABE. Belo Horizonte, 4 a 11 de novembro de 1928, edited by Silva Arlette Pinto de Oliveira, 11-16. Brasília: Instituto Nacional de Estudos e Pesquisas Educacionais Anísio Teixeira.

Vidal, Diana Gonçalves, e Rabelo, Rafaela Silva 2020. Movimento internacional da Educação Nova. Minas Gerais: Fino Traço.

Xavier, Libânia Nacif. 1999. O Brasil como laboratório: educação e ciências sociais no projeto do Centro Brasileiro de Pesquisas Educacionais, 1950-1960. Bragança Paulista: Edusf.

Steffani, Maria Helena, e Vieira, Fernando. 2013. Planetários. http://site.mast.br/pdf_volume_2/planetarios. pdf. Accessed: January 3, 2019.

\section{SOURCES AND COLLECTIONS:}

Brazilian Education Association. Diverse documents relating to the 4th National Education Conference. Folder A05-15. Carmem Jordão Collection, Rio De Janeiro.

Letter 1 dated 20/08/1931 - Letter on Carl Zeiss company headed paper to $A B E$, addressed to the chairman of the organizing commission of the $4^{\text {th }}$ National Education Conference, Fernando Magalhães.

Letter 2 dated 20/08/1931 - Letter on Carl Zeiss company headed paper to $A B E$, addressed to the chairman of the organizing commission of the $4^{\text {th }}$ National Education Conference, Fernando Magalhães.

Letter 3 dated 25/08/1931 - Letter on Carl Zeiss company headed paper to Miss Eva Louis Hyde, Bennet College.

Letter 4 dated 10/12/1931 - Letter on Carl Zeiss company headed paper to $A B E$, addressed to the chairman of the organizing commission of the $4^{\text {th }}$ National Education Conference, Fernando Magalhães.

\section{NATIONAL DIGITAL NEWSPAPER LIBRARY}

Gazeta de Notícias. Rio de Janeiro, January 15th 1928, p. 3, c. IV and V. Available at: http://memoria.bn.br/ docreader/1037 30_05/24650 Accessed: January 9, 2019.
O Jornal. Rio de Janeiro, January 15th 1928, p. 1, c. I. Available at: http://memoria.bn.br/docreader/110523_02/36057 Accessed: January 9, 2019.

O Imparcial. Rio de Janeiro, January 15th 1928, p. 1, c. I. Available at: http://memoria.bn.br/docreader/107670_02/33932 Accessed: January 9, 2019.

Diário da Noite. Rio de Janeiro, August 6th 1931, p. 2, c. IV and V. Available at: http://memoria.bn.br/ docreader/221961_01/7237 Accessed: January 9, 2019.

Jornal do Commercio. Rio de Janeiro, August 20th 1931, p. 3, c. IV. Available at: http://memoria.bn.br/ docreader/364568_12/11651 Accessed: January 9, 2019.

Jornal do Brasil. Rio de Janeiro, April 9th 1927, p. 14, c. II. Available at: http://memoria.bn.br/docreader/030015_04/54681 Accessed: January 9, 2019.

O Cruzeiro. Rio de Janeiro, October 31st 1931, Edition 0052. p. 26-27. Available at: http://memoria.bn.br/ docreader/003581/6124 Accessed: January 9, 2019. 